\title{
Intermittent pacing therapy favorably modulates infarct remodeling
}

\author{
André Uitterdijk ${ }^{1} \cdot$ Tirza Springeling ${ }^{1,2} \cdot$ Kevin C. M. Hermans ${ }^{3}$. \\ Daphne Merkus ${ }^{1}$ • Vincent J. de Beer ${ }^{1}$. Charlotte Gorsse-Bakker ${ }^{1}$. \\ Eric Mokelke $^{4,5} \cdot$ Evangelos P. Daskalopoulos $^{3} \cdot$ Piotr A. Wielopolski ${ }^{2}$. \\ Jack P. M. Cleutjens ${ }^{6}$-W. Matthijs Blankesteijn ${ }^{3}$. Frits W. Prinzen ${ }^{7}$. \\ Willem J. van der Giessen ${ }^{1} \cdot$ Robert-Jan M. van Geuns $^{1,2} \cdot$ Dirk J. Duncker $^{1}$
}

Received: 20 August 2014 / Accepted: 27 March 2017/Published online: 6 April 2017

(c) The Author(s) 2017. This article is an open access publication

\begin{abstract}
Despite early revascularization, remodeling and dysfunction of the left ventricle (LV) after acute myocardial infarction (AMI) remain important therapeutic targets. Intermittent pacing therapy (IPT) of the LV can limit infarct size, when applied during early reperfusion. However, the effects of IPT on post-AMI LV remodeling and infarct healing are unknown. We therefore investigated the effects of IPT on global LV remodeling and infarct geometry in swine with a 3-day old AMI. For this purpose, fifteen pigs underwent $2 \mathrm{~h}$ ligation of the left circumflex coronary artery followed by reperfusion. An epicardial pacing lead was implanted
\end{abstract}

Electronic supplementary material The online version of this article (doi:10.1007/s00395-017-0616-3) contains supplementary material, which is available to authorized users.

André Uitterdijk and Tirza Springeling contributed equally.

Dirk J. Duncker

d.duncker@erasmusmc.nl

1 Department of Cardiology, Ee-2351, Erasmus MC, University Medical Center Rotterdam, PO Box 2040, 3000 CA Rotterdam, The Netherlands

2 Department of Radiology, Erasmus MC, Rotterdam, The Netherlands

3 Department of Pharmacology, CARIM, Maastricht University, Maastricht, The Netherlands

4 Boston Scientific Corporation, St. Paul, MN, USA

5 Present Address: Medical Products Division, W.L. Gore and Associates, Flagstaff, AZ, USA

6 Department of Pathology, CARIM, Maastricht University, Maastricht, The Netherlands

7 Department of Physiology, CARIM, Maastricht University, Maastricht, The Netherlands in the peri-infarct zone. After three days, global LV remodeling and infarct geometry were assessed using magnetic resonance imaging (MRI). Animals were stratified into MI control and IPT groups. Thirty-five days post-AMI, follow-up MRI was obtained and myofibroblast content, markers of extracellular matrix (ECM) turnover and Wnt/frizzled signaling in infarct and non-infarct control tissue were studied. Results showed that IPT had no significant effect on global LV remodeling, function or infarct mass, but modulated infarct healing. In MI control pigs, infarct mass reduction was principally due to a $26.2 \pm 4.4 \%$ reduction in infarct thickness $(P \leq 0.05)$, whereas in IPT pigs it was mainly due to a $35.7 \pm 4.5 \%$ decrease in the number of infarct segments $(P \leq 0.05)$, with no significant change in infarct thickness. Myofibroblast content of the infarct zone was higher in IPT $(10.9 \pm 2.1 \%)$ compared to MI control $(5.4 \pm 1.6 \% ; P \leq 0.05)$. Higher myofibroblast presence did not coincide with alterations in expression of genes involved in ECM turnover or Wnt/frizzled signaling at 5 weeks follow-up. Taken together, IPT limited infarct expansion and altered infarct composition, showing that IPT influences remodeling of the infarct zone, likely by increasing regional myofibroblast content.

Keywords Myocardial infarction · Myofibroblasts $\cdot$ Infarct geometry $\cdot$ Infarct expansion $\cdot$ Infarct healing $\cdot$ Swine

\section{Introduction}

The prevalence of heart failure continues to rise worldwide $[6,31]$. An important risk factor for heart failure is leftventricular (LV) remodeling following acute myocardial 
infarction (AMI), with infarct size as its principal determinant [6, 14, 28]. Despite advances in the treatment of AMI and subsequent cardiac remodeling, a need exists for novel adjunctive therapies [5]. Current strategies under investigation for cardioprotection include pharmacological agents or application of brief mechanical interruptions of coronary blood flow either before ischemia or during early reperfusion to protect the myocardium by reducing infarct size [9, 12]. In addition, evidence from experimental studies shows that intermittent pacing therapy (IPT) is capable of limiting infarct size not only when applied prior to ischemia [21, 46] but also when applied during early reperfusion $[1,3,45]$, resulting in a trend towards blunting of subsequent LV remodeling [2]. Importantly, a recent clinical study confirmed pacing therapy to be effective at reducing infarct size in patients, when started at reperfusion [47].

Presently, it remains incompletely understood whether IPT is capable of limiting LV remodeling independent of its protection against acute myocardial necrosis, i.e., when started a few days after reperfusion. Consequently, the aim of the present study was to investigate the effects of dyssynchronous IPT of the left ventricle (IPTVVI), when started in the sub-acute phase after reperfusion, in a large animal model of transmural reperfused AMI produced by a transient coronary artery occlusion (CAO). For this purpose, swine were subjected to a $120-$ min $\mathrm{CAO}$ followed by reperfusion, three days after which they underwent cine-MRI and delayed enhancement MRI (DE-MRI) to assess global LV remodeling and function as well as infarct geometry. Subsequently animals received IPTVVI $(3 \times 5 \mathrm{~min}$ b.i.d.) throughout the five weeks post-AMI.

\section{Materials and methods}

Experiments were performed in thirty-six 5-6-month-old Yorkshire $\mathrm{x}$ Landrace pigs of either sex and were conducted in compliance with the "Guide for the Care and use of Laboratory Animals" and after written approval of the Animal Care Committee of the Erasmus MC.

\section{Acute effects of IPTAAI and IPTVVI on LV function}

In four chronically instrumented swine we assessed safety and proper functioning of the pacemakers by investigating the acute hemodynamic responses to intermittent dyssynchronous pacing of the left ventricle (IPTVVI) in comparison with intermittent synchronous atrial pacing (IPTAAI). See Supplemental Methods and Results for detailed protocol and results.

\section{Effects of chronic IPTVVI on global LV and regional infarct remodeling}

\section{Surgery}

Swine $(n=27)$ were sedated [ketamine $20 \mathrm{mg} / \mathrm{kg}$ intramuscular (IM); midazolam, $1 \mathrm{mg} / \mathrm{kg}$, IM; atropine $1 \mathrm{mg}$, IM], anesthetized [thiopental sodium, $15 \mathrm{mg} / \mathrm{kg}$, intravenous (IV)] and intubated. Anesthesia was maintained with fentanyl $(20 \mu \mathrm{g} / \mathrm{kg} / \mathrm{h}$, IV) until LCx occlusion, followed by isoflurane $(1-2 \% \mathrm{v} / \mathrm{v})$. Antibiotic prophylaxis consisted of procaine benzylpenicillin $(20 \mathrm{mg} / \mathrm{kg}$, IM) and dihydrostreptomycin $(25 \mathrm{mg} / \mathrm{kg}$, IM). Following thoracotomy via the third left intercostal space, a polyvinylchloride catheter was placed in the aortic arch, the pericardium was opened and the proximal LCx was dissected. A unipolar epicardial lead was actively fixed in the anticipated anterior infarct border zone, followed by $2 \mathrm{~h}$ of LCx occlusion. The pericardium and chest were closed and the animals were allowed to recover, receiving analgesia (buprenorphine, $0.01 \mathrm{mg} / \mathrm{kg} /$ day, IM) for $48 \mathrm{~h}$. Pacemakers were interrogated weekly. Six swine died during the AMI procedure; two swine died during the first $24 \mathrm{~h}$ post-AMI; one swine died during transportation to the MRI at 3 days.

\section{Experimental protocol}

Three days after AMI, cardiac MRI was performed. Swine were sedated and intubated as described above. Mechanical ventilation and peri-imaging breath holds were performed using a mobile ventilator. During MRI, anesthesia was maintained with fentanyl $(20 \mu \mathrm{g} / \mathrm{kg} / \mathrm{h}, \mathrm{IV})$ and thiopental sodium (100 mg bolus). Muscle relaxation was achieved using pancuronium bromide (2-4 mg, IV). Post-imaging, animals received antibiotic prophylaxis as described above and were allowed to recover. Then, animals were randomized to either MI control or IPTVVI and pacemakers remained switched off (MI control) or were started (IPTVVI). Importantly, none of the remaining 18 swine died prematurely after stratification into MI control $(n=11)$ or IPTVVI $(n=7)$ groups. The IPTVVI pacing protocol was applied every $12 \mathrm{~h}$ (6 am and $6 \mathrm{pm})$, consisting of three times 5-min of pacing at 30 beats/min above sinus rhythm (AV-delay $10 \mathrm{~ms}$ ) separated by 5 -min of normal sinus rhythm. Post hoc analysis of pacemaker readouts could not confirm proper pacing in one IPTVVI animal, whereas in the MI control group two animals received unplanned indiscriminate pacing. Consequently, for final analysis six swine were included in the IPTVVI group and nine swine were included in the MI control group. At one and five weeks post-AMI arterial blood samples were collected in subsets of animals $(n=5$ per group). Five weeks after onset of treatment, cardiac MRI 
measurements were repeated and animals were killed for histological and molecular analysis of the infarct zone.

\section{Cardiac magnetic resonance imaging}

Cardiac MRI was performed and analyzed on a 3T scanner as described before [4, 38]. Global and regional cardiac function and infarct geometry were assessed at baseline ( 3 days post-AMI), i.e., before treatment and at 5 weeks follow-up (see Supplemental Methods and Results).

\section{Biomarkers}

Arterial blood samples were collected 1 and 5 weeks postAMI in EDTA tubes $(n=5)$ and plasma was stored at $-80{ }^{\circ} \mathrm{C}$. Markers of inflammation (TNF $\left.\alpha\right)$ and extracellular matrix turnover (MMP-9, TIMP-1) were quantified using dedicated porcine enzyme-linked immunosorbent assays (ELISA) according to manufacturer's instructions (see Supplemental Methods and Results).

\section{Histology}

At 5 weeks follow-up, transverse sections of infarct tissue were fixed in $4 \%$ formaldehyde and embedded in paraffin. To quantify myofibroblasts in the infarct area, sections were stained for alpha smooth muscle actin ( $\alpha$ SMA; [44]; see Supplemental Methods and Results). Data were expressed as myofibroblast area/total tissue area (\%). In addition, lateral wall myocardial tissue of five additional weight-matched healthy swine was quantified for myofibroblast content.

To quantify total collagen content and discriminate collagen fiber type in the infarct area, sections were stained with $0.1 \%$ picrosirius red in saturated picric acid $(n=6$ per group). Collagen content in the infarct region was expressed as stained area/total infarct area (\%) using bright field images (four photos per animal). Collagen fiber types were assessed by circular polarizing microscopy in which five polarizing colors were discerned; red (type I collagen, mature), orange, yellow, green, and teal (type III collagen, immature) to discriminate between mature and immature collagen and were expressed as polarized area of interest/total polarized area $(\%)$.

\section{$R T-P C R$}

Infarct tissue from all animals as well as normal myocardium of the weight-matched non-MI control group $(n=5)$ was homogenized and RNA was isolated. The isolated RNA was assessed for concentration and purity (A260/A280 ratio), and reverse-transcribed into cDNA (see Supplemental Methods and Results). The expression of 21 genes related to myofibroblast presence, regulation or differentiation, were quantified as well as seven genes involved in extracellular matrix turnover (see Table 2 and Supplemental Methods and Results). Quantification of gene expression was performed using the comparative $C_{\mathrm{t}}$ $\left(\Delta C_{\mathrm{t}}\right)$ method and results are expressed as ratios to the housekeeping gene cyclophilin.

\section{Statistical analysis}

All data are expressed as mean \pm SEM. Data were analyzed using two-way (time $\times$ treatment) RM-ANOVA followed by post hoc testing, when appropriate, or within treatment group differences with paired $t$ testing, and between treatment group differences with unpaired $t$ testing (SPSS 15.0, IBM, Armonk, NY, USA). One-way ANOVA testing with Fisher's least significant difference correction (LSD) was used to analyze gene expression data. $P \leq 0.05$ (two-tailed) was considered statistically significant.

\section{Results}

\section{Acute effects of IPTAAI and IPTVVI on LV function}

Safety and proper functioning of ventricular pacing protocols were ascertained in four pigs as evidenced by the absence of ventricular arrhythmias and a programmed increase in heart rate of 30 beats/min (see Supplemental Methods and Results and Supplemental Figure 1 for details).

\section{Effects of chronic IPTVVI on global LV and regional infarct remodeling}

Table 1 summarizes global LV anatomy, function and infarct geometry data at baseline and at follow-up. In MI control animals, two hours of occlusion of the LCx resulted in AMI that comprised $31 \pm 2 \%$ of the LV. Already at 3-day post-AMI, LV end-diastolic volume (EDV, $80 \pm 3 \mathrm{ml}$ ) and end-systolic volume (ESV, $54 \pm 3 \mathrm{ml}$ ) were larger as compared to EDV $(68 \pm 3 \mathrm{ml})$ and ESV $(30 \pm 2 \mathrm{ml})$ in a historical control group of healthy adolescent swine of similar age [30]. MI resulted in a depressed ejection fraction (EF) of $33 \pm 2 \%$, compared to $55 \pm 3 \%$ in normal healthy swine [30]. During the 5 weeks follow-up, total LV mass did not change, as the increase in mass of the remote myocardium was balanced by an equivalent decrease in infarct mass (Table 1). EDV and ESV further increased to $113 \pm 5$ and $68 \pm 3 \mathrm{ml}$, respectively, with EF tending to slightly recover from $33 \pm 2$ to $40 \pm 2 \%(P=0.06)$. The increase in EDV over 
Table 1 Global LV function and infarct geometry

\begin{tabular}{|c|c|c|}
\hline & \multicolumn{2}{|l|}{ Post-MI } \\
\hline & 3 days $\mathrm{BL}$ & 37 days FU \\
\hline \multicolumn{3}{|c|}{ Global LV anatomy and function } \\
\hline \multicolumn{3}{|c|}{ Body weight (kg) } \\
\hline MI control & $29 \pm 0$ & $38 \pm 1 *$ \\
\hline IPT & $28 \pm 1$ & $37 \pm 1^{*}$ \\
\hline \multicolumn{3}{|l|}{ LV mass $(\mathrm{g})$} \\
\hline MI control & $56 \pm 1$ & $58 \pm 1$ \\
\hline IPT & $55 \pm 2$ & $55 \pm 1$ \\
\hline \multicolumn{3}{|c|}{ Heart rate $(\mathrm{bpm})$} \\
\hline MI control & $93 \pm 3$ & $80 \pm 6$ \\
\hline IPT & $100 \pm 6$ & $78 \pm 11$ \\
\hline \multicolumn{3}{|c|}{ End-diastolic volume (ml) } \\
\hline MI control & $80 \pm 3$ & $113 \pm 5^{*}$ \\
\hline IPT & $81 \pm 2$ & $110 \pm 8^{*}$ \\
\hline \multicolumn{3}{|c|}{ End-systolic volume (ml) } \\
\hline MI control & $54 \pm 3$ & $68 \pm 3^{*}$ \\
\hline IPT & $53 \pm 2$ & $67 \pm 8$ \\
\hline \multicolumn{3}{|c|}{ Stroke volume (ml) } \\
\hline MI control & $27 \pm 2$ & $45 \pm 4^{*}$ \\
\hline IPT & $28 \pm 2$ & $43 \pm 3^{*}$ \\
\hline \multicolumn{3}{|c|}{ Ejection fraction $(\%)$} \\
\hline MI control & $33 \pm 2$ & $40 \pm 2 * *$ \\
\hline IPT & $35 \pm 3$ & $40 \pm 3^{*}$ \\
\hline \multicolumn{3}{|c|}{ Infarct geometry } \\
\hline \multicolumn{3}{|c|}{ Remote LV mass (g) } \\
\hline MI control & $39 \pm 1$ & $47 \pm 1^{*}$ \\
\hline IPT & $38 \pm 1$ & $46 \pm 1^{*}$ \\
\hline \multicolumn{3}{|c|}{ Infarct mass $(\mathrm{g})$} \\
\hline MI control & $17.6 \pm 1.4$ & $11.7 \pm 0.8^{*}$ \\
\hline IPT & $17.1 \pm 1.2$ & $9.3 \pm 0.9 *,+$ \\
\hline \multicolumn{3}{|c|}{ Infarct size $(\% \mathrm{LV})$} \\
\hline MI control & $31 \pm 2$ & $20 \pm 1 *$ \\
\hline IPT & $31 \pm 2$ & $17 \pm 2 *$ \\
\hline \multicolumn{3}{|c|}{ Infarct thickness (mm) } \\
\hline MI control & $6.2 \pm 0.2$ & $4.5 \pm 0.2^{*}$ \\
\hline IPT & $5.9 \pm 0.2$ & $4.9 \pm 0.3$ \\
\hline \multicolumn{3}{|c|}{ Infarct length (\#slices) } \\
\hline MI control & $7.8 \pm 0.6$ & $8.3 \pm 0.6$ \\
\hline IPT & $8.8 \pm 0.3$ & $8.0 \pm 0.5^{*}$ \\
\hline \multicolumn{3}{|c|}{ Infarct length (mm) } \\
\hline MI control & $47 \pm 4$ & $50 \pm 4$ \\
\hline IPT & $53 \pm 2$ & $48 \pm 3^{*}{ }^{\dagger}$ \\
\hline \multicolumn{3}{|c|}{ Infarct circumference (\#segments) } \\
\hline MI control & $13.5 \pm 0.8$ & $12.0 \pm 1.1$ \\
\hline IPT & $13.6 \pm 1.6$ & $9.4 \pm 1.3^{*},^{\dagger}$ \\
\hline \multicolumn{3}{|c|}{ Infarct circumference $(\mathrm{mm})$} \\
\hline MI control & $62 \pm 3$ & $65 \pm 6$ \\
\hline IPT & $61 \pm 5$ & $52 \pm 5$ \\
\hline
\end{tabular}

Table 1 continued

\begin{tabular}{lll}
\hline & \multicolumn{2}{l}{ Post-MI } \\
\cline { 2 - 3 } 3 days BL & 37 days FU \\
\hline Total \# infarcted segments & \\
MI control & $73 \pm 8$ & $71 \pm 9$ \\
IPT & $90 \pm 9$ & $58 \pm 8^{*, \dagger}$ \\
\hline
\end{tabular}

Data are mean \pm SEM; MI control, $n=9$; IPT, $n=6$

$B L$ baseline, $F U$ follow-up, $L V$ left ventricle

* $P<0.05$, vs. corresponding BL

** $P<0.10$, vs. corresponding BL

${ }^{\dagger} P<0.05,{ }^{\dagger \dagger} P<0.10$, change by IPT vs. change in control

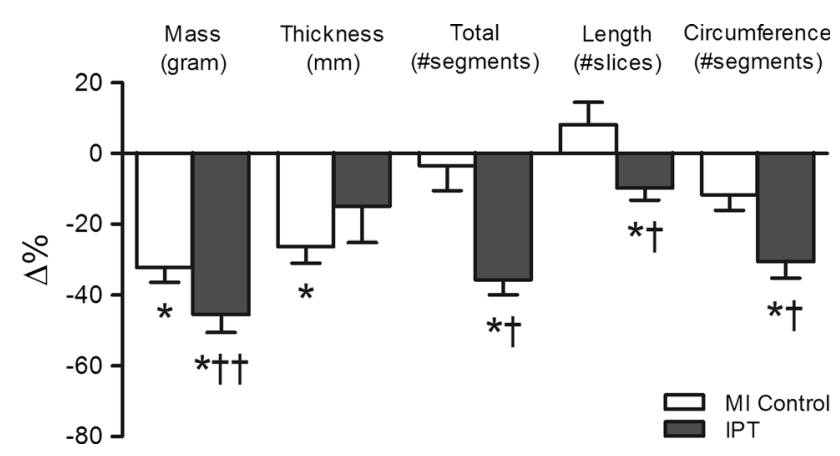

Fig. 1 Effect of IPTVVI on infarct geometry. Percent changes in infarct geometry from 3 days baseline values at 5-week follow-up in eight MI control (white bars) and six IPTVVI (gray bars) swine. Shown are changes in infarct mass, infarct thickness, total number of infarcted segments, number of infarcted slices, and average circumferential infarct length. Data are mean \pm SEM; $* P \leq 0.05$ vs. corresponding $\mathrm{BL} ;{ }^{\dagger} P \leq 0.05,{ }^{\dagger} P \leq 0.10$, vs. change in MI control

time in swine with MI was in part attributable to physiological growth of the heart, as EDV in healthy swine showed a modest increase from $68 \pm 3$ to $91 \pm 6 \mathrm{ml}$ [30]. In contrast to the increase in ESV over time in swine with MI (from $54 \pm 3$ to $68 \pm 3 \mathrm{ml}$ ), there was a negligible increase in ESV in healthy swine (from $30 \pm 2$ to $32 \pm 3 \mathrm{ml}$ ), associated with an increase in EF from $55 \pm 3$ to $64 \pm 3 \%$ [30]. These findings indicate that MI resulted in LV remodeling and dysfunction that was already observed early at 3 days and was sustained throughout the 5 weeks follow-up period.

Global LV and infarct geometry parameters showed no significant differences between IPTVVI and MI control (Table 1) at the 3-day post-AMI baseline. Moreover, the changes in global LV anatomy and function during 5 weeks of follow-up were not different between IPTVVI and MI control. However, infarct geometry responded markedly to IPTVVI (Table 1; Fig. 1). In MI control animals, infarct mass decreased over time as a result of a significant decrease in infarct thickness with no significant changes in infarct length or circumference, and no changes 
in the total number of infarcted segments. In contrast, in IPTVVI animals, the reduction in infarct mass was primarily due to a decrease in total number of infarcted segments (comprising reductions in both infarct length and circumference), with no significant decrease in infarct thickness. The latter could have played a role in preventing the reduction in infarct mass from reaching statistical significance compared to MI control group $(P=0.07$; Fig. 1$)$.

\section{Infarct composition}

Histological quantification of $\alpha$ SMA positive cells in the infarct region showed a significantly higher amount of myofibroblasts in the infarct area in IPTVVI $(10.9 \pm 2.1 \%)$ than in MI control $(5.4 \pm 1.6 \%)$ swine (Fig. 2). aSMA quantification of referent control tissue (excluding the coronary microvasculature) equaled zero and confirmed the absence of myofibroblasts in healthy myocardial tissue. mRNA-expression data for aSMA between IPTVVI and MI control confirmed the IPTVVIinduced increase in $\alpha \mathrm{SMA}$ in histological findings $(P=0.04$, see Table 2$)$.

Canonical Wnt/frizzled signaling is activated upon injury including myocardial infarction [13, 50]. Indeed, the increased myofibroblast presence in infarcted tissue as compared to non-MI tissue was accompanied by activation of the Wnt/frizzled signaling, as evidenced by increased presence of the Fzd2 receptor and its co-receptor LRP5. However, downstream targets of canonical Wnt/frizzled signaling (axis inhibition protein 2 (Axin), adenomatous polyposis coli (APC) and $\beta$-catenin) were not altered in infarcted tissue as compared to non-MI tissue. The inflammatory markers transforming growth factor $\beta 1$ (TGF $\beta 1$ ) and TGF $\beta 2$ were also not altered, while TGF $\beta 3$ was increased in $\mathrm{MI}$ as compared to non-MI tissue, and its receptors TGF $\beta 1 \mathrm{R}$ and TGF $\beta 2 R$ were decreased. Overall, TGF $\beta$-signaling appeared to be reduced in MI as compared to non-MI tissue, as evidenced by a decrease in PAI1. However, IPTVVI had no effect on either Wnt/frizzled or TGF $\beta$-signaling
(Table 2), while circulating levels of TNF $\alpha$ were also not different between IPT and MI control animals (Fig. 3).

Consistent with the role of myofibroblasts in extracellular matrix $(\mathrm{ECM})$ production and turnover, Col1a1-expression at follow-up was significantly increased in IPTVVI animals compared to MI control $(P=0.04)$, while Col3a1 expression was elevated in both MI control and IPT animals (Table 2).

Histological quantification of total collagen content showed no differences between MI control and IPTVVI infarct collagen content at 5 weeks follow-up ( $73 \pm 3$ vs. $78 \pm 4 \%$, respectively, $P=0.34$ ). Furthermore, collagen composition, expressed as the percentage type I collagen fiber (red, mature; $52 \pm 7$ vs. $65 \pm 6 \%, P=0.22$ ) and type III collagen (teal, immature; $10 \pm 2$ vs. $7 \pm 1 \%$, respectively, $P=0.12$ ) were not different between groups (See Supplemental Methods and Results for individual data).

Circulating plasma levels of extracellular matrix turnover (MMP-9 and TIMP-1), measured at 1 and 5 weeks post-AMI, did not differ significantly between treatment groups (Fig. 3), although there was a trend towards an increase in TIMP-1 expression in the infarcted area in IPTVVI vs. MI control (Table 2, $P=0.09$, two-tailed), that together with the increased Collal expression may reflect increased ECM turnover.

\section{Discussion}

The present study is the first to investigate the effects of dyssynchronous intermittent ventricular pacing (IPTVVI), initiated three days after acute myocardial infarction (AMI) and continued for 5 weeks, on global and regional LV remodeling and infarct geometry in a clinically relevant large animal model. The major findings were that (1) IPTVVI had no effect on global LV remodeling or function, but (2) had a marked effect on infarct remodeling by decreasing the number of infarcted segments without
Fig. 2 IPTVVI increases myofibroblast presence in the infarct region. Left panel $\alpha \mathrm{SMA}$ stained infarct tissue of two MI control and two IPTVVI swine (magnification $\times 20$ ). Brown staining indicates myofibroblasts. Right panel percent $\alpha$ SMA-positive cells in infarct tissue from eight MI control (white bar) and six IPTVVI (gray bar) swine. Data are mean $\pm \mathrm{SEM} ; * P \leq 0.05$ vs. MI control

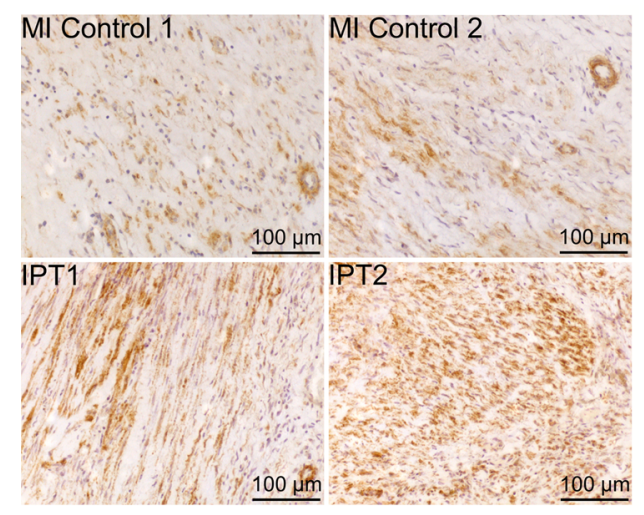


Table 2 Expression of genes related to myofibroblasts and extracellular matrix biology

\begin{tabular}{|c|c|c|c|}
\hline & Non-MI control & MI control & IPT \\
\hline \multicolumn{4}{|c|}{ Myofibroblast presence, regulation and differentiation } \\
\hline aSMA & $0.5 \pm 0.1$ & $0.7 \pm 0.1$ & $1.2 \pm 0.3^{*}, \dagger$ \\
\hline Vimentin & $2.7 \pm 0.6$ & $1.7 \pm 0.5$ & $1.6 \pm 0.4$ \\
\hline Desmin & $0.4 \pm 0.1$ & $0.4 \pm 0.1$ & $0.3 \pm 0.1$ \\
\hline SPARC & $0.5 \pm 0.1$ & $1.6 \pm 0.5$ & $1.9 \pm 0.7^{* *}$ \\
\hline $\begin{array}{l}\text { Tenascin- } \\
\text { C }\end{array}$ & $0.1 \pm 0.1$ & $1.5 \pm 0.9$ & $0.6 \pm 0.2^{*}$ \\
\hline VEGF-A & $1.3 \pm 0.4$ & $0.6 \pm 0.1 * *$ & $0.6 \pm 0.3^{* *}$ \\
\hline$\beta$-Catenin & $0.7 \pm 0.3$ & $0.6 \pm 0.1$ & $0.4 \pm 0.1$ \\
\hline TGF $\beta 1$ & $0.8 \pm 0.3$ & $0.8 \pm 0.1$ & $0.6 \pm 0.1$ \\
\hline TGF $\beta 2$ & $2.7 \pm 1.0$ & $1.8 \pm 0.6$ & $1.4 \pm 0.1$ \\
\hline TGF $\beta 3$ & $0.2 \pm 0.1$ & $6.1 \pm 2.2^{* *}$ & $5.2 \pm 1.8$ \\
\hline TGF $\beta 1 R$ & $3.3 \pm 1.3$ & $1.1 \pm 0.2^{*}$ & $0.9 \pm 0.1^{*}$ \\
\hline TGF $\beta 2 R$ & $1.7 \pm 0.5$ & $0.8 \pm 0.1^{*}$ & $0.7 \pm 0.1^{*}$ \\
\hline Fzd2 & $0.4 \pm 0.1$ & $1.5 \pm 0.4 * *$ & $1.7 \pm 0.3^{*}$ \\
\hline Fzd4 & $0.9 \pm 0.2$ & $1.3 \pm 0.3$ & $0.9 \pm 0.2$ \\
\hline LRP5 & $0.2 \pm 0.1$ & $0.8 \pm 0.2^{*}$ & $0.5 \pm 0.2$ \\
\hline LRP6 & $1.1 \pm 0.3$ & $0.7 \pm 0.1$ & $0.7 \pm 0.1$ \\
\hline LOX & $2.1 \pm 0.6$ & $2.0 \pm 0.7$ & $3.6 \pm 0.7$ \\
\hline APC & $0.8 \pm 0.2$ & $0.8 \pm 0.2$ & $0.8 \pm 0.1$ \\
\hline Axin 2 & $3.1 \pm 1.2$ & $3.6 \pm 1.2$ & $3.5 \pm 1.0$ \\
\hline ID1 & $0.2 \pm 0.1$ & $0.6 \pm 0.2$ & $0.7 \pm 0.2$ \\
\hline PAI1 & $2.6 \pm 1.2$ & $1.0 \pm 0.2^{* *}$ & $0.6 \pm 0.2^{*}$ \\
\hline \multicolumn{4}{|c|}{ Extracellular matrix composition and turnover } \\
\hline Col1a1 & $0.9 \pm 0.2$ & $2.1 \pm 0.7$ & $4.7 \pm 1.3^{*, \dagger}$ \\
\hline Col1a2 & $2.7 \pm 0.7$ & $1.9 \pm 0.6$ & $3.5 \pm 1.3$ \\
\hline Col3a1 & $0.3 \pm 0.1$ & $1.7 \pm 0.5^{* *}$ & $2.0 \pm 0.6^{*}$ \\
\hline MMP-2 & $1.4 \pm 0.4$ & $1.7 \pm 0.5$ & $2.5 \pm 0.7$ \\
\hline MMP-9 & $1.9 \pm 0.6$ & $4.5 \pm 1.6$ & $4.5 \pm 1.5$ \\
\hline TIMP-1 & $0.1 \pm 0.1$ & $1.5 \pm 0.4$ & $3.4 \pm 1.5^{*}+\dagger$ \\
\hline CTGF & $1.6 \pm 1.3$ & $1.8 \pm 0.5$ & $0.9 \pm 0.3$ \\
\hline
\end{tabular}

Data are presented as mean \pm SEM and expressed as ratios to housekeeping gene cyclophilin; MI control: $n=9$; IPT: $n=6$, nonMI control: $n=5$

$A P C$ adenomatous polyposis coli, Axin axis inhibition protein, $\alpha S M A$ alpha smooth muscle actin, $\mathrm{Col}$ collagen, $C T G F$ connective tissue growth factor, $F z d$ frizzled, $I D$ inhibitor of DNA binding, $L O X$ lysyl oxidase, $L R P$ low-density lipoprotein receptor-related protein, $M M P$ matrix metalloproteinase, $P A I$ plasminogen activator inhibitor, $R T$ $q P C R$ reverse transcriptase quantitative polymerase chain reaction, $S P A R C$ secreted protein acidic and rich in cysteine, $T G F$ transforming growth factor, TIMP tissue inhibitor of metalloproteinases, $V E G F-A$ vascular endothelial growth factor A

$* P \leq 0.05$ vs. non-MI control

$* * P \leq 0.10$ vs. non-MI control

${ }^{\dagger} P \leq 0.05$ IPT vs. corresponding MI control

${ }^{\dagger} P \leq 0.10$ IPT vs. corresponding MI control changing infarct thickness. (3) Additionally, IPTVVI increased myofibroblast content in the infarcted area, (4) without changing circulating markers of inflammation and extracellular matrix turnover. These findings provide evidence that intermittent electrical stimulation of the left ventricle may represent a novel means to modulate scar remodeling after MI.

\section{IPT in AMI and post-AMI remodeling}

Several studies in swine [21] and rabbits [45, 46] have shown that pretreatment with ventricular, but not atrial [27], pacing is capable of limiting myocardial infarct size. Subsequent studies have demonstrated that not only preconditioning [21, 45, 46], but also postconditioning with brief periods of ventricular pacing in the early reperfusion phase [1-3, 45] can limit myocardial infarct size. Moreover, the effects of this early protection against myocardial necrosis were sustained over a six week period, resulting in a trend towards blunted LV remodeling and improved LV function [2]. The present study is the first to investigate the effects of prolonged IPT on infarct remodeling, independent of its protection against acute myocardial necrosis in a preclinical animal model. The results of this study clearly demonstrate that IPTVVI started 3 days after reperfusion, at a time when necrosis can no longer be affected, significantly influenced remodeling of the infarct region.

Early studies in humans in the pre-thrombolysis era, reported disproportionate thinning and stretching of the infarcted segment [18, 48, 49]. Recent post-thrombolysis studies in humans with reperfused AMI confirm that regional myocardial wall thinning represents (transmural) myocardial infarction [35]. Furthermore, limited scar burden is associated with improved contractility [35] and blunted remodeling [28], whereas rupture-prone cardiac aneurysms are the consequence of continued ventricular wall thinning [22]. Also, late dilatation of the LV after primary percutaneous intervention remains of clinical significance [37] and may represent a potential target of IPTVVI. Thus, the IPTVVI-induced alteration of infarct geometry may mitigate the sequence of events leading to ventricular wall thinning and limit LV remodeling. Although significant changes in infarct geometry and composition were observed in the present study, these alterations did not yet translate into favorable global LV remodeling at 5 weeks follow-up. This finding, which is similar to previous observations with cell-therapy studies in swine [29], as well as humans [19], with AMI, suggests that more pronounced changes in infarct geometry are required to translate into benefits at the global LV level. 

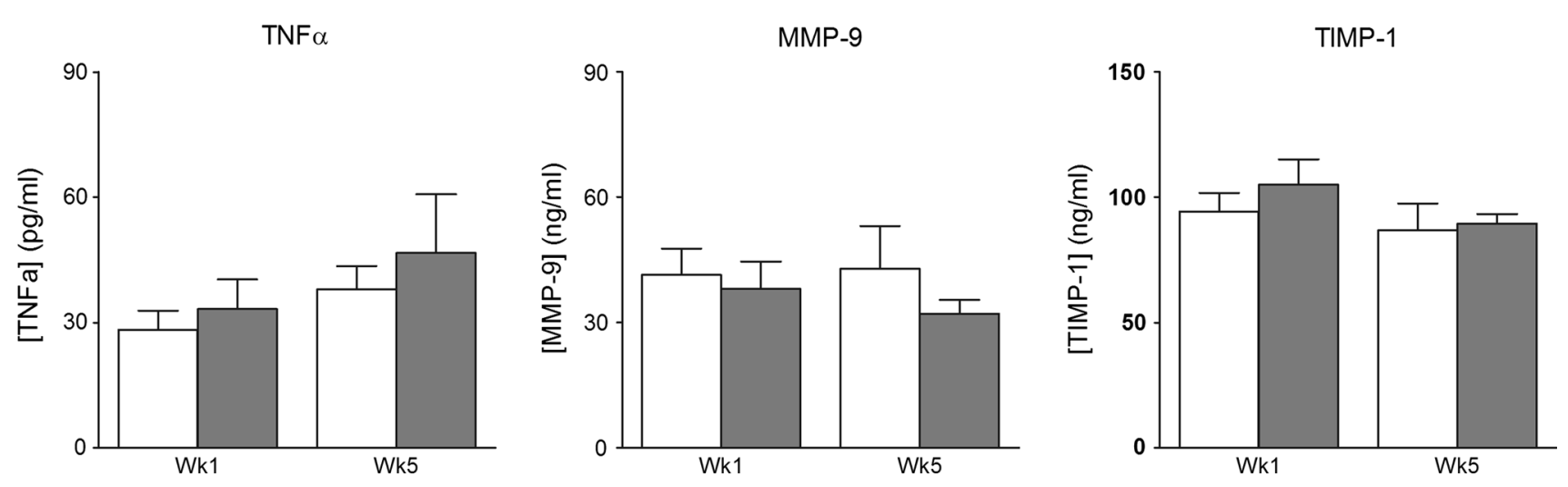

Fig. 3 Circulating levels of markers of extracellular matrix and inflammation. Markers for extracellular matrix and inflammation in arterial plasma of five control (white bars) and five IPTVVI (gray bars) swine. Data are mean $\pm \mathrm{SEM} ; * P \leq 0.05$ vs. MI control

This may also explain why a recent clinical study on periinfarct zone pacing after AMI (PRomPT Trial) reported no difference in LV function or geometry at 18 -month followup [39]. A limitation of the present study is that we investigated only a single algorithm of pacing therapy, so that we cannot exclude that other algorithms or pacing protocols may produce larger regional effects that do translate into global LV improvements [3]. Clearly, future studies, are necessary to optimize the onset, timing, duration and mode of pacing therapy.

\section{IPT and infarct geometry: role of myofibroblasts}

The infarct zone is increasingly being appreciated as an area with relevant biological activity and therapeutic potential $[8,40]$. Cardiac fibroblasts, including the active collagen-secreting myofibroblasts, are the dominant cell type in the infarct region and are recognized as essential in infarct remodeling [7, 20, 41, 43]. Myofibroblasts typically appear in the infarct area at 4-5 days after AMI, reach a peak at 1-2 weeks and continue to reside up to at least 4 weeks [10] and possibly months to years [43]. In the present study, IPTVVI, started at three days post-AMI, increased myofibroblast numbers in the infarct zone significantly. Myofibroblasts could have contributed to the geometric changes in the infarct region produced by IPTVVI in several ways. First, in the infarcted myocardium, myofibroblasts are responsible for collagen turnover thus contributing to the delicate balance between ECM synthesis and degradation [43]. Consistent with a role of myofibroblasts in ECM synthesis, Collal expression was increased by IPTVVI. Moreover, a trend towards increased expression of TIMP-1 was found in infarcts of IPTVVI animals $(P=0.09)$ compared to MI control, which is consistent with the observations of Mukherjee et al. [32] that TIMP-1 co-localizes with myofibroblasts within the infarct zone. Although the increased Colla1 expression and the trend towards an increase in TIMP-1 did not translate into an increase in collagen as measured with histology, it is plausible that myofibroblasts, a rich source of bioactive molecules [34], modulated infarct geometry by affecting ECM turnover. Second, myofibroblasts are capable of tonic contraction, and could therefore improve structural integrity of the scar and increase mechanical strength in the (sub)acute phase [43]. Particularly, the latter is in concordance with the geometrical changes observed in the present study.

The exact mechanism by which IPTVVI influenced myofibroblast presence was not determined in the present study. However, it is well known that LV pacing results in considerable changes in LV contraction patterns, even in the peri-infarct zone [25, 45], resulting in alterations in regional stretch and loading conditions [17, 33, 36, 46]. Since mechanical tension is an important stimulus for cardiac fibroblast to myofibroblast differentiation $[11,15,16,26]$, it is likely that regional alterations in myocardial stretch produced by IPTVVI stimulated resident fibroblasts to differentiate into myofibroblasts.

No change in circulating arterial plasma levels of the inflammatory marker TNF $\alpha$ was found in IPTVVI vs. MI control swine, at either 1 or 5 weeks after AMI, indicating that the effect of pacing on release of these proteins in pigs with infarcts was not discernible in the systemic circulation even as early as 1 week post-AMI. Hence, altered myofibroblast presence within the infarcted area of IPTVVI treated swine was likely the result of local effects on myofibroblast recruitment and/or differentiation. As myofibroblast migration and differentiation are initiated in the early phase after MI, expression studies at 5-week follow-up can by definition not identify which molecular mechanisms underlie the higher myofibroblast presence. Interestingly, the expression of the Fzd2 receptor, involved in myofibroblast homeostasis [24], was increased in both MI control and IPTVVI treated animals, which may have served to maintain the myofibroblasts in the infarcted region. It has previously been shown that activation of the 
TGF $\beta$ signaling pathway increases myofibroblast presence [23], and therefore it is possible that this pathway was only activated in the early phase of IPTVVI. This is also suggested by a study in swine, in which continuous low dose electrical stimulation within the infarct region, not only resulted in higher numbers of myofibroblasts, but also in elevated TGF $\beta$-R1 activity, when measured as early as one week after onset of stimulation [32]. Expression of TGF $\beta$ $\mathrm{R} 1$ and PAI-1, a measure for TGF $\beta-\mathrm{R} 1$ signaling were downregulated in both the MI control and IPTVVI group as compared to healthy control animals underlining the transient nature of the local inflammatory responses at the molecular level to regional electrical stimulation. Although in agreement with a previous study from our laboratory [42], TGF $\beta 3$ was upregulated in the infarcted tissue, this was not altered by IPTVVI, making it unlikely that activation of the TGF $\beta$-pathway at five weeks follow-up contributed to the increased presence of the myofibroblasts in the IPTVVI treated animals.

In conclusion, the present study shows that 5 weeks of IPTVVI, a regionally targeted non-pharmaceutical approach that was safe (no arrhythmias and maintained cardiac output), favorably influenced the infarct remodeling process, likely by increasing myofibroblast content in the infarct region. Thus, whereas MI control swine showed a reduction in infarct mass over the 5-week follow-up period, which was principally due to infarct thinning, IPTVVI resulted in a reduction in infarct mass that was principally due to a decrease in the number of infarcted LV segments while infarct thinning was prevented. Histological assessment revealed increased numbers of myofibroblasts in the infarct zone. Taken together, these findings suggest that IPT in the peri-infarct zone represents a novel adjunctive therapy to favorably modulate infarct healing in patients with acute myocardial infarction.

\section{Compliance with ethical standards}

Conflict of interest This study was financially supported by Boston Scientific/Guidant. Eric Mokelke is a former Boston Scientific Employee.

Open Access This article is distributed under the terms of the Creative Commons Attribution 4.0 International License (http://crea tivecommons.org/licenses/by/4.0/), which permits unrestricted use, distribution, and reproduction in any medium, provided you give appropriate credit to the original author(s) and the source, provide a link to the Creative Commons license, and indicate if changes were made.

\section{References}

1. Abwainy A, Babiker F, Akhtar S, Benter IF (2016) Endogenous angiotensin-(1-7)/Mas receptor/NO pathway mediates the cardioprotective effects of pacing postconditioning. Am J Physiol
Heart Circ Physiol 310:H104-H112. doi:10.1152/ajpheart.00121. 2015

2. Babiker FA, Lorenzen-Schmidt I, Mokelke E, Vanagt WY, Delhaas T, Waltenberger J, Cleutjens JP, Prinzen FW (2010) Long-term protection and mechanism of pacing-induced postconditioning in the heart. Basic Res Cardiol 105:523-533. doi:10. 1007/s00395-010-0095-2

3. Babiker FA, van Golde J, Vanagt WY, Prinzen FW (2012) Pacing postconditioning: impact of pacing algorithm, gender, and diabetes on its myocardial protective effects. J Cardiovasc Transl Res 5:727-734. doi:10.1007/s12265-012-9390-7

4. Baks T, van Geuns RJ, Biagini E, Wielopolski P, Mollet NR, Cademartiri F, Boersma E, van der Giessen WJ, Krestin GP, Duncker DJ, Serruys PW, de Feyter PJ (2005) Recovery of left ventricular function after primary angioplasty for acute myocardial infarction. Eur Heart J 26:1070-1077. doi:10.1093/eurheartj/ ehi131

5. Bell RM, Botker HE, Carr RD, Davidson SM, Downey JM, Dutka DP, Heusch G, Ibanez B, Macallister R, Stoppe C, Ovize M, Redington A, Walker JM, Yellon DM (2016) 9th Hatter Biannual Meeting: position document on ischaemia/reperfusion injury, conditioning and the ten commandments of cardioprotection. Basic Res Cardiol 111:41. doi:10.1007/s00395-016-0558-1

6. Braunwald E (2013) Heart failure. JACC Heart Fail 1:1-20. doi:10.1016/j.jchf.2012.10.002

7. Brown RD, Ambler SK, Mitchell MD, Long CS (2005) The cardiac fibroblast: therapeutic target in myocardial remodeling and failure. Annu Rev Pharmacol Toxicol 45:657-687. doi:10. 1146/annurev.pharmtox.45.120403.095802

8. Cleutjens JP, Blankesteijn WM, Daemen MJ, Smits JF (1999) The infarcted myocardium: simply dead tissue, or a lively target for therapeutic interventions. Cardiovasc Res 44:232-241. doi:10. 1016/j.cardiores.2007.01.014

9. Dirksen MT, Laarman GJ, Simoons ML, Duncker DJ (2007) Reperfusion injury in humans: a review of clinical trials on reperfusion injury inhibitory strategies. Cardiovasc Res 74:343-355. doi:10.1016/j.cardiores.2007.01.014

10. Frangogiannis NG, Michael LH, Entman ML (2000) Myofibroblasts in reperfused myocardial infarcts express the embryonic form of smooth muscle myosin heavy chain (SMemb). Cardiovasc Res 48:89-100. doi:10.1016/S0008-6363(00)00158-9

11. Fujiu K, Nagai R (2013) Contributions of cardiomyocyte-cardiac fibroblast-immune cell interactions in heart failure development. Basic Res Cardiol 108:357. doi:10.1007/s00395-013-0357-x

12. Hausenloy DJ, Yellon DM (2013) Myocardial ischemia-reperfusion injury: a neglected therapeutic target. J Clin Invest 123:92-100. doi:10.1172/Jci62874

13. Hermans KC, Daskalopoulos EP, Blankesteijn WM (2012) Interventions in Wnt signaling as a novel therapeutic approach to improve myocardial infarct healing. Fibrogenesis Tissue Repair 5:16. doi:10.1186/1755-1536-5-16

14. Heusch G, Libby P, Gersh B, Yellon D, Bohm M, Lopaschuk G, Opie L (2014) Cardiovascular remodelling in coronary artery disease and heart failure. Lancet 383:1933-1943. doi:10.1016/ S0140-6736(14)60107-0

15. Hinz B, Gabbiani G (2003) Mechanisms of force generation and transmission by myofibroblasts. Curr Opin Biotechnol 14:538-546. doi:10.1016/j.copbio.2003.08.006

16. Hinz B, Mastrangelo D, Iselin CE, Chaponnier C, Gabbiani G (2001) Mechanical tension controls granulation tissue contractile activity and myofibroblast differentiation. Am J Pathol 159:1009-1020. doi:10.1016/S0002-9440(10)61776-2

17. Huang CH, Wang JS, Chiang SC, Wang YY, Lai ST, Weng ZC (2004) Brief pressure overload of the left ventricle preconditions rabbit myocardium against infarction. Ann Thorac Surg 78:628-633. doi:10.1016/jathoracsur.2004.01.046 
18. Hutchins GM, Bulkley BH (1978) Infarct expansion versus extension: two different complications of acute myocardial infarction. Am J Cardiol 41:1127-1132. doi:10.1016/00029149(78)90869-X

19. Janssens S, Dubois C, Bogaert J, Theunissen K, Deroose C, Desmet W, Kalantzi M, Herbots L, Sinnaeve P, Dens J, Maertens J, Rademakers F, Dymarkowski S, Gheysens O, Van Cleemput J, Bormans G, Nuyts J, Belmans A, Mortelmans L, Boogaerts M, Van de Werf F (2006) Autologous bone marrow-derived stemcell transfer in patients with ST-segment elevation myocardial infarction: double-blind, randomised controlled trial. Lancet 367:113-121. doi:10.1016/S0140-6736(05)67861-0

20. Jivraj N, Phinikaridou A, Shah AM, Botnar RM (2014) Molecular imaging of myocardial infarction. Basic Res Cardiol 109:397. doi:10.1007/s00395-013-0397-2

21. Koning MM, Gho BC, van Klaarwater E, Opstal RL, Duncker DJ, Verdouw PD (1996) Rapid ventricular pacing produces myocardial protection by nonischemic activation of $\mathrm{KATP}^{+}$channels. Circulation 93:178-186. doi:10.1161/01.CIR.93.1.178

22. Kumar Goud P, Bakkannavar SM, Chinmayee P (2013) Cardiac aneurysm: a nature's way of correction. Am J Forensic Med Pathol 34:228-230. doi:10.1097/PAF.0b013e3182a186c8

23. Laeremans H, Hackeng TM, van Zandvoort MA, Thijssen VL, Janssen BJ, Ottenheijm HC, Smits JF, Blankesteijn WM (2011) Blocking of frizzled signaling with a homologous peptide fragment of wnt3a/wnt5a reduces infarct expansion and prevents the development of heart failure after myocardial infarction. Circulation 124:1626-1635. doi:10.1161/CIRCULATIONAHA.110. 976969

24. Laeremans H, Rensen SS, Ottenheijm HC, Smits JF, Blankesteijn WM (2010) Wnt/frizzled signalling modulates the migration and differentiation of immortalized cardiac fibroblasts. Cardiovasc Res 87:514-523. doi:10.1093/cvr/cvq067

25. Lewis CW, Owen CH, Zipprich DA, Sabiston DC Jr, Smith PK, Glower DD (1993) The effects of local ventricular pacing on recovery from regional myocardial ischemia. J Surg Res 54:360-367. doi:10.1006/jsre.1993.1058

26. Lindner D, Zietsch C, Tank J, Sossalla S, Fluschnik N, Hinrichs S, Maier L, Poller W, Blankenberg S, Schultheiss HP, Tschope C, Westermann D (2014) Cardiac fibroblasts support cardiac inflammation in heart failure. Basic Res Cardiol 109:428. doi:10. 1007/s00395-014-0428-7

27. Marber MS, Walker DM, Eveson DJ, Walker JM, Yellon DM (1993) A single five minute period of rapid atrial pacing fails to limit infarct size in the in situ rabbit heart. Cardiovasc Res 27:597-601. doi:10.1093/cvr/27.4.597

28. Masci PG, Ganame J, Francone M, Desmet W, Lorenzoni V, Iacucci I, Barison A, Carbone I, Lombardi M, Agati L, Janssens S, Bogaert J (2011) Relationship between location and size of myocardial infarction and their reciprocal influences on post-infarction left ventricular remodelling. Eur Heart J 32:1640-1648. doi:10.1093/eurheartj/ehr064

29. Moelker AD, Baks T, van den Bos EJ, van Geuns RJ, de Feyter PJ, Duncker DJ, van der Giessen WJ (2006) Reduction in infarct size, but no functional improvement after bone marrow cell administration in a porcine model of reperfused myocardial infarction. Eur Heart J 27:3057-3064. doi:10.1093/eurheartj/ehl401

30. Moelker AD, Baks T, Wever KM, Spitskovsky D, Wielopolski PA, van Beusekom HM, van Geuns RJ, Wnendt S, Duncker DJ, van der Giessen WJ (2007) Intracoronary delivery of umbilical cord blood derived unrestricted somatic stem cells is not suitable to improve LV function after myocardial infarction in swine. J Mol Cell Cardiol 42:735-745. doi:10.1016/j.yjmcc.2007.01.005

31. Mosterd A, Hoes AW (2007) Clinical epidemiology of heart failure. Heart (British Cardiac Society) 93:1137-1146. doi:10. 1136/hrt.2003.025270
32. Mukherjee R, Rivers WT, Ruddy JM, Matthews RG, Koval CN, Plyler RA, Chang EI, Patel RK, Kern CB, Stroud RE, Spinale FG (2010) Long-term localized high-frequency electric stimulation within the myocardial infarct: effects on matrix metalloproteinases and regional remodeling. Circulation 122:20-32. doi:10. 1161/CIRCULATIONAHA.110.936872

33. Ovize M, Kloner RA, Przyklenk K (1994) Stretch preconditions canine myocardium. Am J Physiol 266:H137-H146

34. Porter KE, Turner NA (2009) Cardiac fibroblasts: at the heart of myocardial remodeling. Pharmacol Ther 123:255-278. doi:10. 1016/j/pharmthera.2009.05.002

35. Shah DJ, Kim HW, James O, Parker M, Wu E, Bonow RO, Judd RM, Kim RJ (2013) Prevalence of regional myocardial thinning and relationship with myocardial scarring in patients with coronary artery disease. JAMA 309:909-918. doi:10.1001/jama.2013. 1381

36. Shuros AC, Salo RW, Florea VG, Pastore J, Kuskowski MA, Chandrashekhar Y, Anand IS (2007) Ventricular preexcitation modulates strain and attenuates cardiac remodeling in a swine model of myocardial infarction. Circulation 116:1162-1169. doi:10.1161/Circulationaha.107.696294

37. Springeling T, Kirschbaum SW, Rossi A, Baks T, Karamermer Y, Schulz C, Ouhlous M, Duncker DJ, Moelker A, Krestin GP, Serruys PW, de Feyter P, van Geuns RJ (2013) Late cardiac remodeling after primary percutaneous coronary interventionfive-year cardiac magnetic resonance imaging follow-up. Circ J 77:81-88. doi:10.1253/circj.CJ-12-0043

38. Springeling T, Uitterdijk A, Rossi A, Gorsse-Bakker C, Wielopolski PA, van der Giessen WJ, Krestin GP, de Feyter PJ, Duncker DJ, van Geuns RJ (2013) Evolution of reperfusion postinfarction ventricular remodeling: new MRI insights. Int J Cardiol 169:354-358. doi:10.1016/j.ijcard.2013.09.005

39. Stone GW, Chung ES, Stancak B, Svendsen JH, Fischer TM, Kueffer F, Ryan T, Bax J, Leon A, Investigators PRT (2016) Periinfarct zone pacing to prevent adverse left ventricular remodelling in patients with large myocardial infarction. Eur Heart $\mathbf{J}$ 37:484-493. doi:10.1093/eurheartj/ehv436

40. Sun Y, Kiani MF, Postlethwaite AE, Weber KT (2002) Infarct scar as living tissue. Basic Res Cardiol 97:343-347. doi:10.1007/ s00395-002-0365-8

41. Turner NA (2011) Therapeutic regulation of cardiac fibroblast function: targeting stress-activated protein kinase pathways. Future Cardiol 7:673-691. doi:10.2217/fca.11.41

42. Uitterdijk A, Hermans KC, de Wijs-Meijler DP, Daskalopoulos EP, Reiss IK, Duncker DJ, Matthijs Blankesteijn W, Merkus D (2016) UM206, a selective Frizzled antagonist, attenuates adverse remodeling after myocardial infarction in swine. Lab Invest 96:168-176. doi:10.1038/labinvest.2015.139

43. van den Borne SW, Diez J, Blankesteijn WM, Verjans J, Hofstra L, Narula J (2010) Myocardial remodeling after infarction: the role of myofibroblasts. Nat Rev Cardiol 7:30-37. doi:10.1038/ nrcardio.2009.199

44. van den Borne SW, van de Schans VA, Strzelecka AE, VervoortPeters HT, Lijnen PM, Cleutjens JP, Smits JF, Daemen MJ, Janssen BJ, Blankesteijn WM (2009) Mouse strain determines the outcome of wound healing after myocardial infarction. Cardiovasc Res 84:273-282. doi:10.1093/cvr/cvp207

45. Vanagt WY, Cornelussen RN, Baynham TC, Van Hunnik A, Poulina QP, Babiker F, Spinelli J, Delhaas T, Prinzen FW (2007) Pacinginduced dyssynchrony during early reperfusion reduces infarct size. J Am Coll Cardiol 49:1813-1819. doi:10.1016/j.jacc.2007.01.070

46. Vanagt WY, Cornelussen RN, Poulina QP, Blaauw E, Vernooy K, Cleutjens JP, van Bilsen M, Delhaas T, Prinzen FW (2006) Pacing-induced dys-synchrony preconditions rabbit myocardium against ischemia/reperfusion injury. Circulation 114:I264-I269. doi:10.1161/Circulationaha.105.000893 
47. Waltenberger J, Gelissen M, Bekkers SC, Vainer J, van Ommen V, Eerens F, Ruiters A, Holthuijsen A, Cuesta P, Strauven R, Mokelke E, Gorgels A, Prinzen FW (2014) Clinical pacing postconditioning during revascularization after AMI. JACC Cardiovasc Imaging 7:620-626. doi:10.1016/j.jcmg.2014.01.017

48. Weisman HF, Healy B (1987) Myocardial infarct expansion, infarct extension, and reinfarction: pathophysiologic concepts. Prog Cardiovasc Dis 30:73-110. doi:10.1016/0033-0620(87)90004-1
49. Weiss JL, Marino PN, Shapiro EP (1991) Myocardial infarct expansion: recognition, significance and pathology. Am J Cardiol 68:35D-40D. doi:10.1016/0002-9149(91)90259-N

50. Whyte JL, Smith AA, Helms JA (2012) Wnt signaling and injury repair. Cold Spring Harb Perspect Biol 4:a008078. doi:10.1101/ cshperspect.a008078 